\title{
National Income Accounting and Environment: A Case Study of Waterlogging and Salinity in Pakistan
}

\author{
A. R. Kemal, FAIZ BILqUEES, and Zafar MAHMOOD
}

\section{INTRODUCTION}

Whereas irrigation plays a crucial role in improving agricultural productivity, it has resulted in waterlogging and salinity problems in Pakistan due to both water seepage from canals and overdoses of water encouraged by inappropriate water pricing practices. ${ }^{1}$ As many as 2.2 million hectares of land forming 13 percent of the cultivated area in Pakistan suffer from an acute problem of waterlogging and salinity, i.e., water table is less than 5 feet from the normal surface level. [See Government of Pakistan (1993)]. Despite the government's effort to resolve the problem through an expansive network of public tubewells under the salinity control and reclamation project (SCARP), the problem seems to have worsened over time.

The higher water doses may increase the growth of output in the short run, but by degrading the agricultural lands and increasing impurities of potable water, etc., they adversely affect the long-run growth. These adverse effects of the inappropriate irrigation practices on agricultural productivity are generally not accounted for in the national income accounting system. Accordingly, there is a need to account for the forgone economic, social, and environmental benefits. In this regard, the environmental resource accounting provides a valuable information base for integrated development planning and policy. The approach allows for segregation and elaboration of all environment-related flows and stocks of traditional accounts, linkage of physical accounts with monetary environmental accounts and balance sheets, assessment of environmental costs and benefits, accounting for the maintenance of tangible wealth, and elaboration and measurement of the indicators of environmentally-adjusted production and income.

A. R. Kemal is Joint Director and Faiz Bilquees and Zafar Mahmood are both Senior Research Economist at the Pakistan Institute of Development Economics, Islamabad.

${ }^{1}$ Revenue from water charges could finance only two-thirds of the current expenditures. Water rates are based on the crops sown rather than on the water used. [See Chaudhry (1993)]. 
The objective of the present study is to assess the impact of waterlogging and salinity on the environment of Pakistan, by employing an environmental resource accounting methodology specifically designed for the valuation of environmental degradation. The methodology has been applied to the Mona Reclamation Experimental Project located in Tehsil Bhalwal of Sargodha District in the Punjab province. The area has been selected due to three main reasons. First, the water table depth in the area has been quite high, resulting in severe problems of waterlogging and salinity. Second, benchmark data and the data on two intervening periods are also available. Third, the project was initiated in the sixties but received little support from the government in the eighties which allows us to estimate the costs and benefits of such programmes and to compute the environmental cost of inappropriate water pricing.

\section{ENVIRONMENTAL CONSEQUENCES OF WATERLOGGING AND SALINITY FOR MAJOR CROPS}

According to the soil survey undertaken by WAPDA ${ }^{2}$ in 1981, about 2.9 million acres, i.e., 7 percent of the gross cultivated area, had a water table depth (WTD) of less than three feet; and another 6.2 million acres, i.e., 15 percent, had a WTD between three and six feet. The seventh and the Eighth Five-Year Plans report 5.3 and 5.4 million acres with a WTD of less than 5 feet and 21.9 and 20.3 million acres with a WTD of less than 10 feet.

Depending on the crop, a higher water table induces adverse effects on yields. There is land degradation and the consequent decline in the yields of different crops as the water table rises. Production becomes uneconomic around two feet.

As much as 8 percent of the irrigated area is severely salt-affected, while another 6 percent is affected moderately. Most of these areas are in Sindh, where 28 percent of all irrigated land is affected. Ahmed and Kutcher (1992) have used the threshold tolerance level technique developed by Maas and Hoffman (1977) to assess the impact of salinity on crop yields. They estimated the basic parameters of threshold tolerance and percentage decline in yields of different crops in the Indus Basin for unit increases above the threshold levels. We may also note that 6 percent of the irrigated area experiences a minimum yield decline, between 2 percent for cotton and 60 percent for rice, while 8 percent of the area experiences minimum yield declines, i.e., 38 percent for cotton to 100 percent for rice.

Soil salinity survey of WAPDA has also estimated saline levels of 7.5 and 8.8 electrical conductivity. These levels are seen to apply to 72 percent and 21 percent of the area in Sindh and Punjab, respectively.

${ }^{2}$ For details of the review of the public sector policies to control waterlogging and salinity, see Kemal, Bilquees, and Mahmood (1994). 


\section{SYSTEM OF INTEGRATED ENVIRONMENTAL AND ECONOMIC ACCOUNTING}

The existing System of National Accounts (SNA) provides useful indicators of economic performance in terms of gross domestic product, investment, savings, depreciation of capital, etc. However, the system fails to take account of the environmental degradation caused by economic growth. Therefore, the existing system overstates the growth and fails to reflect the sustainability of growth. The need for a broader assessment of growth and welfare in terms of modified national accounts is, therefore, quite obvious.

While the SNA presently in vogue in Pakistan and other countries takes into consideration the depreciation of physical capital to arrive at Net National Product, it fails to account for the depletion of natural resources. It needs to be noted that many of the goods and services provided by environmental and natural resources are not traded in the markets. Therefore, no monetary value is assigned to them by the markets and, as a result, they are not reflected in the SNA. Even when the natural resources are traded in the markets, the markets do not internalise the goods and services supplied by these resources due to the structural limitations of the market mechanism. [See Gilbert, Kuik, and Arntzem (1990)].

The System of Integrated Environmental and Economic Accounting (SEEA) provides a meaningful inter-relationship between the natural environment and the economy that is both comprehensive and consistent. ${ }^{3}$ This synthesis of economic and environmental analysis necessitates a data system in which different parts are built on comparable concepts and are closely linked to each other.

With a view to ascertaining whether a project is feasible and optimal, the costbenefit analysis is generally carried out. The analysis may also be used to examine the effect of an environmental project on the long-run growth. Such an analysis calls for an identification of important environmental effects, their quantification, placing monetary values, and carrying out economic analysis.

The net contribution of the project may be written as:

$$
N_{B}=B_{d}+B_{e}-C_{d}-C_{p}-C_{e}
$$

where,

$$
\begin{aligned}
& N_{B}=\text { net benefits as the contribution to national income, } \\
& B_{d}=\text { direct benefits, } B_{e}=\text { environmental benefits, } \\
& C_{d}=\text { direct costs, } C_{p}=\text { protective costs, and } \\
& C_{e}=\text { environmental costs. }
\end{aligned}
$$

${ }^{3}$ For a review of the methodologies, see Kemal, Bilquees, and Mahmood (1994). Also see Alfsen, Bye, and Lorentsen (1987); Corniere (1986); El Sarafy and Lutz (1989); Gilbert, Kuik, and Arntzem (1990); Hueting (1980); Hufschmidt and Dixon (1986); Landefeld and Hines (1985); Miller and Upton (1985); Pearce, Markandya, and Barbier (1989); Pearce (1989); and Repetto, Wells, Beer, and Rossini (1989). 
It may be pointed out that the application of the cost-benefit analysis to account for environmental considerations is not straight-forward. This is because environmental costs and benefits often occur over a long period of time, and are difficult to predict and quantify. Nevertheless, the extent to which environmental costs and benefits are incorporated into the cost-benefit analysis, with values assigned to damages, will establish the fact that the environmental services are not free and the damages accruing from a project are accounted for.

\section{ENVIRONMENTAL DEGRADATION AND MONA PROJECT}

As has been pointed out earlier, water rates in Pakistan have not only been low, they are also not related to the consumption of water. Accordingly, the cultivators have been using excessive dosages of water, culminating in waterlogging and salinity problems. The area covered by Mona project suffered from this dual menace and, accordingly, the government initiated the project in 1965-66. At that time, net profitability per cropped acre was as low as Rs 2.1 per year.

The project consisted of laying tubewells and the drainage lines. However, drainage lines were not dug in the hope that water would not rise to the critical level for about thirty years [Johnson (1988)]. In 1965-66, 138 tubewells were installed and sufficient allocations were made in the budget for operation and maintenance. Productivity started increasing sharply as the project was implemented.

While the normal life of tubewells in Pakistan is taken as 12 years, ${ }^{4}$ they have not been replaced so far. Moreover, the O\&M expenditures have also been slashed down, with the result that the pumpage has gone down considerably. Since the project received adequate funding upto 1977-78, which is incidentally the 12th year of operation, the net profitability started falling at a rapid rate in the subsequent periods. Since there may have been a secular increase in the productivity, reflecting technical change, the entire increase in the growth in productivity can not be attributed to the project. Accordingly, we adjust the growth in productivity by the overall increase in agricultural productivity in Pakistan and estimate the contribution made by the project. The increase in productivity after adjusting for the capital cost indicates the effect of waterlogging and salinity on the output. Since the productivity may even fall in the absence of the project, such estimates are the minimum bound of the losses suffered by the economy due to problems of waterlogging and salinity.

The project is expected to increase the productivity in two ways. First, productivity increases as the condition of the land improves. Second, it allows a

${ }^{4}$ Originally most of the consultants predicted 40- or even 50-year service lives of tubewells. However, on account of the rapid decline in pumpage capacity of the tubewells due to poor maintenance in SCARP-I, the consultants lowered their estimates to 20-25 years of service life for SCARP tubewells. Further, due to continuous rapid decline in the working of wells, it was lowered to 12 years in 1971. [See Government of Punjab (1971)]. 
higher use of intermediate inputs. As a result, farm income increases and the contribution of agriculture to the GDP increases as well.

Waterlogging and salinity affect the productivity of land in two ways. First, they increase the culturable waste and, secondly, they reduce the productivity of cropped acreage. Culturable waste started declining as the project was implemented, but it started increasing in the early Seventies, even though the cropped acreage continued to rise. On the other hand, productivity continued to increase upto the late Seventies as long as the project had sufficient allocations to pump the water and the tubewells had the productive life.

The present study makes use of the cost-benefit analysis approach to evaluate the impact of waterlogging and salinity on the economy. In order to estimate the present value of the streams of costs and benefits, data are required on the value of output, intermediate inputs, capital cost of the project and maintenance cost of the project. Value of the output has been estimated as the incomes from the crop and livestock sub-sectors, while the quantities have been assigned the farm-gate prices. ${ }^{5}$ The farm inputs are evaluated at market prices.

The value-added is simply the difference between the value of output and the material inputs. It may alternatively be defined as the sum total of the payment to production factors, i.e., a sum of wages, rent, interest, and profit. Accordingly, we define

$$
\begin{aligned}
\text { Value-added }=G D P & =w+r+i+f \\
N N P & =G D P-D m \\
A N N P & =N N P-D n
\end{aligned}
$$

where

$$
\begin{aligned}
w & =\text { wages, } r=\text { rent, } i=\text { interest, } \\
f & =\text { profit, } N N P=\text { net national product, } \\
G D P & =\text { gross national product, } \\
D m & =\text { depreciation of man-made capital, } \\
D n & =\text { depreciation of natural resource capital, and } \\
A N N P & =\text { environmentally-adjusted net national product. }
\end{aligned}
$$

Accordingly, the net present value (P.V.) of a project is

$$
\text { P.V. }=K_{0}+\sum_{t=1}\left(Y_{t}-Y_{0}\right) /(1+i)^{t}+\text { Scrap value of Capital } /(1+i)^{t}
$$

${ }^{5}$ These data have been generated through a sample survey of the Mona Project. For details, see Kemal, Bilquees, and Mahmood (1994). 
where

$$
\begin{aligned}
& K_{0}=\text { initial cost of capital, } \\
& Y_{t}=\text { net profitability, } \\
& Y_{0}=\text { base year net profitability, } \\
& i \quad=\text { discount rate, and } \\
& t \quad=\text { time. }
\end{aligned}
$$

Waterlogging and salinity result in ever increasing culturable waste and a decline in productivity. Unfortunately, we do not have any data on the deterioration in productivity and an increase in culturable waste prior to 1965-66. Therefore, we assume that the loss due to waterlogging and salinity is the net gain to productivity as a result of the project. Obviously, such estimates would grossly understate the effect of waterlogging and salinity on the economy.

The Mona project has been quite successful; net present value is not only positive, it is rather high. (See Table 1). Even at a discount rate of 25 percent, the benefit-cost ratio is 3.57. If we assume that the benchmark data have been understated, the project is still quite beneficial. Net present value remained positive, even when it is assumed that the net profitability, instead of Rs 2.1, was as high as Rs 100 in 1965-66.

\section{CONCLUSIONS AND POLICY IMPLICATIONS}

The problems of waterlogging and salinity, despite various incentives, have worsened over time. As much as 7 percent of the gross cultivated area has a watertable depth of less than three feet, while the production virtually becomes uneconomical around two feet. Similarly, about 8 percent of the irrigated area is severely salt-affected, and 6 percent is moderately affected. Besides other factors, waterlogging and salinity in Pakistan have been caused by inappropriate water pricing practices. They have resulted in an increase of culturable waste and have reduced the productivity.

The adverse impact of inappropriate irrigation practices on agricultural productivity is not generally accounted for in the national income accounting system. This paper develops a resource accounting methodology especially designed for the evaluation of environmental degradation caused by inappropriate irrigation practices leading to salinisation and waterlogging. The methodology has been applied to the Mona project, which is located in an area which was severely hit by the problems of waterlogging and salinity.

Study of the Mona project reveals that after the inception of the project, productivity increased due to improvement in the condition of land and a higher use 
Table 1

Net Economic Benefits 1965-66 through the 1993-94 Period

(000 Rupees)

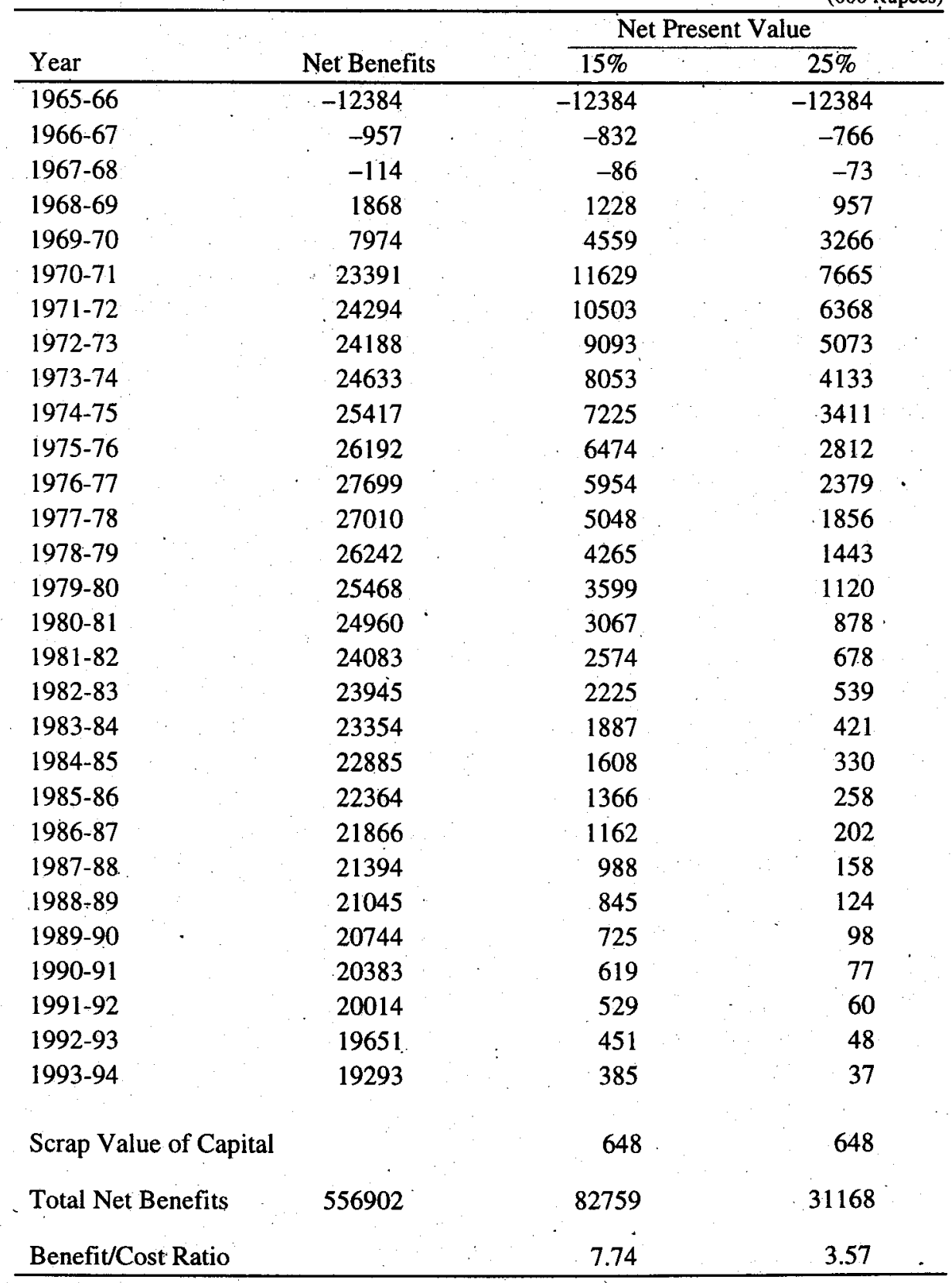


of intermediate inputs. The benefit-cost ratio, even at a discount rate of 25 percent, is 3.57. Moreover, culturable waste declined with the implementation of the project. However, the culturable waste started increasing in the early Seventies as the resources allocated to the project were inadequate. Still, cropping intensity kept on increasing. On the other hand, net profitability per acre continued to increase upto the late Seventies as long as the project had sufficient allocations to pump the water and the tubewells had not outlived their productive life.

The increase in productivity in the Mona project cannot be attributed entirely to the control of waterlogging and salinity. Therefore, the gross increases in productivity have been adjusted for the secular increase in agricultural productivity due to technical progress. The adjustment still shows high pay-off benefit-cost ratio equalling to 2.73 .

The conclusions presented above clearly show that with a view to reducing the culturable waste and increasing the cropping intensity, and thus increasing the productivity of land, there is a need to allocate more resources to the project instead of reducing its allocation. As a matter of fact, there is a need to start new projects like the Mona project. Similarly, there is a need to introduce appropriate water charges, which should be based on the actual water usage rather than the crop cultivated, which is being currently practised. The education of farmers about the ways in which they can efficiently manage water resources and in the ways in which they can effectively reduce the menace of waterlogging and salinity would also be quite useful in the affected areas.

The study emphasises the need for the development of such national income accounts which take into account the foregone economic, social, and environmental benefits. The net gain to productivity due to the special project amounts to the given increase in output because of the project. It is, therefore, essential to reflect the adverse effects of inappropriate irrigation practices on the measures of economic growth. As such, there is also a need to reassess Pakistan's economic performance ever since we have had this problem.

Finally, the study calls for an efforts to improve the existing SNA in vogue in Pakistan to take into account the depletion of natural resources. This, in turn, emphasises the need to improve the information base required for resource management.

\section{REFERENCES}

Ahmed, M., and G. P. Kutcher (1992) Irrigation Planning with Environmental Considerations: A Case Study of Pakistan's Indus Basin. Washington, D. C.: The World Bank.

Alfsen, K. H., T. Bye and L. Lorentsen (1987) Natural Resource Accounting and Analysis: The Norwegian Experience 1978-1986. Oslo: Central Bureau of Statistics. 
Chaudhry, M. G. et al. (1993) The Policy of Irrigation Water Pricing in Pakistan: Aims, Assessment and Needed Redirections. The Pakistan Development Review 32:4 809-821.

Corniere, P. (1986) Natural Resource Accounts in France. An Example: Inland Waters. In Information and Natural Resources. Paris: OECD.

El Serafy, S., and E. Lutz (1989) Environmental and Resource Accounting: An Overview. In Y. J. Ahmad, S. El Serafy and E. Lutz (eds) Environmental Accounting for Sustainable Development. Selected papers from Joint UNEP/ World Bank Workshops. Washington, D. C.: The World Bank.

Gilbert, A., O. Kuik and J. Arntzem (1990) Natural Resource Accounting: Issues Related to Classification and Valuation of Environmental Assets. Paper prepared for UNEP by the Institute of Environmental Studies. Free University of Amsterdam.

Hueting, R. (1980) New Scarcity and Economic Growth. Amsterdam: North-Holland Publishing Co.

Hufschmidt, M. M., and J. A. Dixon (1986) Valuation of Losses of Marine Product Resources Caused by Coastal Development of Tokyo Bag. In J. A. Dixon and M. M. Hufschmidt (eds) Economic Valuation Techniques for the Environment. Baltimore and London: The Johns Hopkins University Press.

Johnson, S. H. (1988) Large Scale Irrigation and Drainage Schemes in Pakistan. In O'mara (ed) Efficiency in Irrigation: The Conjunctive Use of Surface and Ground Water Resources.

Kemal, A. R., F. Bilquees and Z. Mahmood (1994) Economic Valuation of the Salinisation and Waterlogging as a Result of Inappropriate Irrigation in Pakistan. Islamabad: Pakistan Institute of Development Economics.

Landefeld, J. S., and J. R. Hines (1985) National Accounting for Non-renewable Natural Resources in the Mining Industries. Review of Income and Wealth 31:1 $1-20$.

Maas, E. V., and G. J. Hoffman (1977) Crop Salt Tolerance-Current Assessment. Journal of the Irrigation and Drainage Division.

Miller, M. H., and C. W. Upton (1985) A Test of the Hotelling Valuation Principle. Journal of Political Economy 93:1 1-25.

Pakistan, Government of (1993) Eighth Five-Year Plan (1993-98). Islamabad: Planning and Development Division.

Pearce, D. (1989) The Implications of Sustainable Development for Resource Accounting, Project Appraisal, and Integrative Environmental Policy.

Pearce, D., D. Markandya and E. B. Barbier (1989) Blueprint for a Green Economy. London: Earthscan.

Punjab, Government of (1971) Report of the Special Committee on the Working of the SCARPs. Lahore: Land and Water Development Board. WAPDA Press. 
Repetto, R. W., M. M. Wells, C. Beer and F. Rossini (1989) Wasting Assets, Natural Resources in the National Income Accounts. Jakarta: World Resources Institute (June). 